\title{
Assessing the Contribution of Citrus Orchards in Climate Change Mitigation through Carbon Sequestration in Sargodha District, Pakistan
}

\author{
Ghulam Yasin 1,2 D, Muhammad Farrakh Nawaz ${ }^{3}$, Muhammad Zubair ${ }^{2}$, Ihsan Qadir ${ }^{2}$, Aansa Rukya Saleem ${ }^{4}$, \\ Muhammad Ijaz ${ }^{5}$, Sadaf Gul ${ }^{6}$, Muhammad Amjad Bashir ${ }^{7} \mathbb{D}$, Abdur Rehim ${ }^{7}$, Shafeeq Ur Rahman ${ }^{5,8, *}$ \\ and Zhenjie Du ${ }^{8, *}$
}

check for updates

Citation: Yasin, G.; Farrakh Nawaz, M.; Zubair, M.; Qadir, I.; Saleem, A.R.; Ijaz, M.; Gul, S.; Amjad Bashir, M.; Rehim, A.; Rahman, S.U.; et al. Assessing the Contribution of Citrus Orchards in Climate Change Mitigation through Carbon Sequestration in Sargodha District, Pakistan. Sustainability 2021, 13, 12412. https://doi.org/10.3390/ su132212412

Academic Editors: Marco Lauteri and Muhammad Sultan

Received: 26 September 2021 Accepted: 4 November 2021 Published: 10 November 2021

Publisher's Note: MDPI stays neutral with regard to jurisdictional claims in published maps and institutional affiliations.

Copyright: (c) 2021 by the authors Licensee MDPI, Basel, Switzerland. This article is an open access article distributed under the terms and conditions of the Creative Commons Attribution (CC BY) license (https:/ / creativecommons.org/licenses/by/ $4.0 /)$.
1 Department of Forestry Range Wildlife Management, The Islamia University Bahawalpur, Bahawalpur 63100, Pakistan; yasin_2486@yahoo.com

2 Department of Forestry and Range Management, FAS \&T, Bahauddin Zakariya University, Multan 61000, Pakistan; dikhan2000@hotmail.com (M.Z.); drbhabha@bzu.edu.pk (I.Q.)

3 Department of Forestry and Range Management, University of Agriculture Faisalabad, Faisalabad 38000, Pakistan; kf_uaf@yahoo.com

4 Department of Earth and Environmental Sciences, Bahria University, Islamabad 44000, Pakistan; arukya.buic@bahria.edu.pk

5 College of Agriculture, Bahauddin Zakariya University Multan, Bahadur Sub-Campus, Layyah 31200, Pakistan; muhammad.ijaz@bzu.edu.pk

6 Department of Botany, University of Karachi, Karachi 74200, Pakistan; sadafgpk@yahoo.com

7 Department of Soil Science, Faculty of Agricultural Sciences and Technology, Bahauddin Zakariya University, Multan 60800, Pakistan; Amjad.bashir941@gmail.com (M.A.B.); Abdur.rehim@bzu.edu.pk (A.R.)

8 Farmland Irrigation Research Institute, Chinese Academy of Agricultural Sciences, Xinxiang 453000, China

* Correspondence: malikshafeeq1559@gmail.com (S.U.R.); imdzj11@163.com (Z.D.)

\begin{abstract}
Adopting agroforestry practices in many developing countries is essential to combat climate change and diversify farm incomes. This study investigated the above and below-ground biomass and soil carbon of a citrus-based intercropping system in six sites (subdivisions: Bhalwal, Kot Momin, Sahiwal, Sargodha, Shahpur and Silanwali) of District Sargodha, Southeast Pakistan. Tree biomass production and carbon were assessed by allometric equations through a non-destructive approach whereas, soil carbon was estimated at $0-15 \mathrm{~cm}$ and $15-30 \mathrm{~cm}$ depths. Above and below-ground biomass differed significantly, and the maximum mean values (16.61 $\mathrm{Mg} \mathrm{ha}^{-1} \& 4.82 \mathrm{Mg} \mathrm{ha}^{-1}$ ) were computed in Shahpur due to greater tree basal diameter. Tree carbon stock fluctuated from $6.98 \mathrm{Mg} \mathrm{C} \mathrm{ha}^{-1}$ to $10.28 \mathrm{Mg} \mathrm{C} \mathrm{ha}^{-1}$ among selected study sites. The surface soil $(0-15 \mathrm{~cm}) \mathrm{had}$ greater bulk density, organic carbon, and soil carbon stock than the subsoil $(15-30 \mathrm{~cm})$ in the whole study area. The total carbon stock of the ecosystem ranged from $25.07 \mathrm{Mg} \mathrm{C}^{-1}$ to $34.50 \mathrm{Mg} \mathrm{C} \mathrm{ha}^{-1}$ across all study sites, respectively. The above findings enable us to better understand and predict the carbon storage potential of fruit-based agroforestry systems like citrus. Moreover, measuring carbon with simple techniques can produce trustworthy outcomes that enhance the participation of underdeveloped nations in several payment initiatives such as REDD+.
\end{abstract}

Keywords: agroforestry; allometric equations; biomass; carbon stock; organic carbon

\section{Introduction}

The rapid increase of greenhouse gases has been responsible for severe global warming throughout the world in the last few decades [1]. On an average basis, around 9.9 billion metric tons of $\mathrm{CO}_{2}$ have been deposited into the atmosphere annually, causing significant threats to the global environment [2]. According to Stocker [3], severe combustion of fossil fuels and land cover change are the leading anthropogenic causes of this higher $\mathrm{CO}_{2}$ content in the environment. In the background of this higher $\mathrm{CO}_{2}$ amount and global 
warming risk, there is great interest in evolving every possible approach to diminish $\mathrm{CO}_{2}$ concentration emitted through human activities to mitigate climate change [4].

In the terrestrial ecosystem, carbon sequestration is achieved by photosynthesis, which eliminates carbon from the environment and deposits in the biosphere $[5,6]$. Biomass is considered a vital carbon reservoir in the terrestrial ecosystem, thus playing a crucial role in the global carbon cycle [7]. Furthermore, vegetation biomass is greatly dependent on the growth pattern of its various components [8,9] and is strongly influenced by the management efforts [10]. Agroforestry is a well-managed system in which planting of woody trees is done along with crops on the same piece of land [11,12], is currently practised over more than one billion hectares in various parts of the globe and is acting as a major carbon sink around the world [13]. The carbon storage potential of various agroforestry systems is much inconsistent and ranges from 0.29 to $15.21 \mathrm{Mg} \mathrm{ha}^{-1} \mathrm{yr}^{-1}$ around the globe [14].

Orchards are considered an important land-use type and cover approximately $22 \%$ of irrigated agricultural land across the globe [15]. Citrus orchards form almost $20 \%$ of global orchards, including both commercial (61\%) and non-commercial (39\%) types [16]. Citrus trees with medium-high canopy and shade indices have the potential to sequester 36.11-million-ton carbon in the Three Gorges Reservoir region of Chongqing, in which about $88.3 \%$ in soil and $11.7 \%$ in a citrus plant, and the economic value of that was more than 11.49 billion Yuan [17]. Various experimental fruit tree orchards, including citrus, has shown promising potential in fixing carbon [18]. The assimilatory activity by the photosynthetic leaves of these species accounts for a majority of carbon inputs $[1,19]$. Some fruit-based agroforestry systems in the tropics captured about 1.5 to $3.5 \mathrm{Mg} \mathrm{ha}^{-1} \mathrm{yr}^{-1}$ carbon [20].

Fruit tree-based agroforestry systems have been practiced throughout Pakistan, especially in irrigated plains. Along with crops on the same land unit, these systems provide constant and better output in income, food, and fruits to local dwellers [21]. Moreover, fruit-based agroforestry systems are more concerned and compatible as equated to crops [9]. Citrus is the prominent fruit crop and a chief constituent of agroforestry in Pakistan and is commercially interplanted along with the crops. Pakistan is ranked 12th among citrusproducing countries worldwide [22], with a total production of $2.4 \times 10^{5} \mathrm{t}$ annually [23]. Out of the total country area under fruits, $\sim 29.55 \%$ is under citrus, and $\sim 60 \%$ is under Citrus reticulata Blanco, producing more than $75 \%$ of the citrus exports and providing labor days or full-time jobs for more than 75,000 people (about 57 million labor days in production and remaining in marketing sectors) [23].

Keeping in view the production, commercial benefits, and carbon capturing prospective, the citrus-based intercropping agroforestry systems have been studied and acknowledged by several scientists around the globe $[21,24,25]$. Although knowledge regarding the importance of fruit-based land-use practices in combating climate change is growing in the country, information about citrus-based agroforestry systems under local climatic conditions is limited. The present research work was conceived with the primary objective to inspect the current carbon stock and $\mathrm{CO}_{2}$ mitigation potential of a citrus reticulata based planting on farmlands. The study was performed in six towns of District Sargodha, the hub of citrus reticulata based planting, to estimate the accurate dissemination of biomass and carbon stocks in above and below-ground components of the system.

\section{Materials and Methods}

\subsection{Description of Study Sites and Sampling Methodology}

The present research was carried out in six subdivisions of Sargodha, a district in the Punjab province of Pakistan. The study area is an agricultural region having an area of 2260 square miles, and citrus reticulata are commercially inter-planted in the fields along with farm crops across the whole study area. The alluvium of the area is highly fertile for citrus cultivation and is locally known as "Chaj Doab", as depicted in Figure 1. The whole district shares its boundary with salt range on the northern side, whereas the remaining three sides are adjacent to rivers Jhelum and Chenab [26]. The area experiences very long and hot summers with a maximum temperature of $50^{\circ} \mathrm{C}$, while winters are short and cold 
with minimum temperature falls below freezing point in winters at some places. Overall, the area has a $23.8^{\circ} \mathrm{C}$ average temperature with $410 \mathrm{~mm}$ average annual precipitation (https: / / en.climate-data.org/location/2195/). Overall, 60 points were constructed for tree inventory across six sites of districts of Sargodha: Bhalwal, Kot Momin, Sahiwal, Sargodha, Shahpur, and Silanwali to estimate the biomass production and carbon storage both in woody biomass and in soil (Figure 1). Across the whole study area, a total of 300 plots ( $0.405 \mathrm{ha}$ ) with citrus orchards were randomly selected and measured by implementing the lottery method [9].

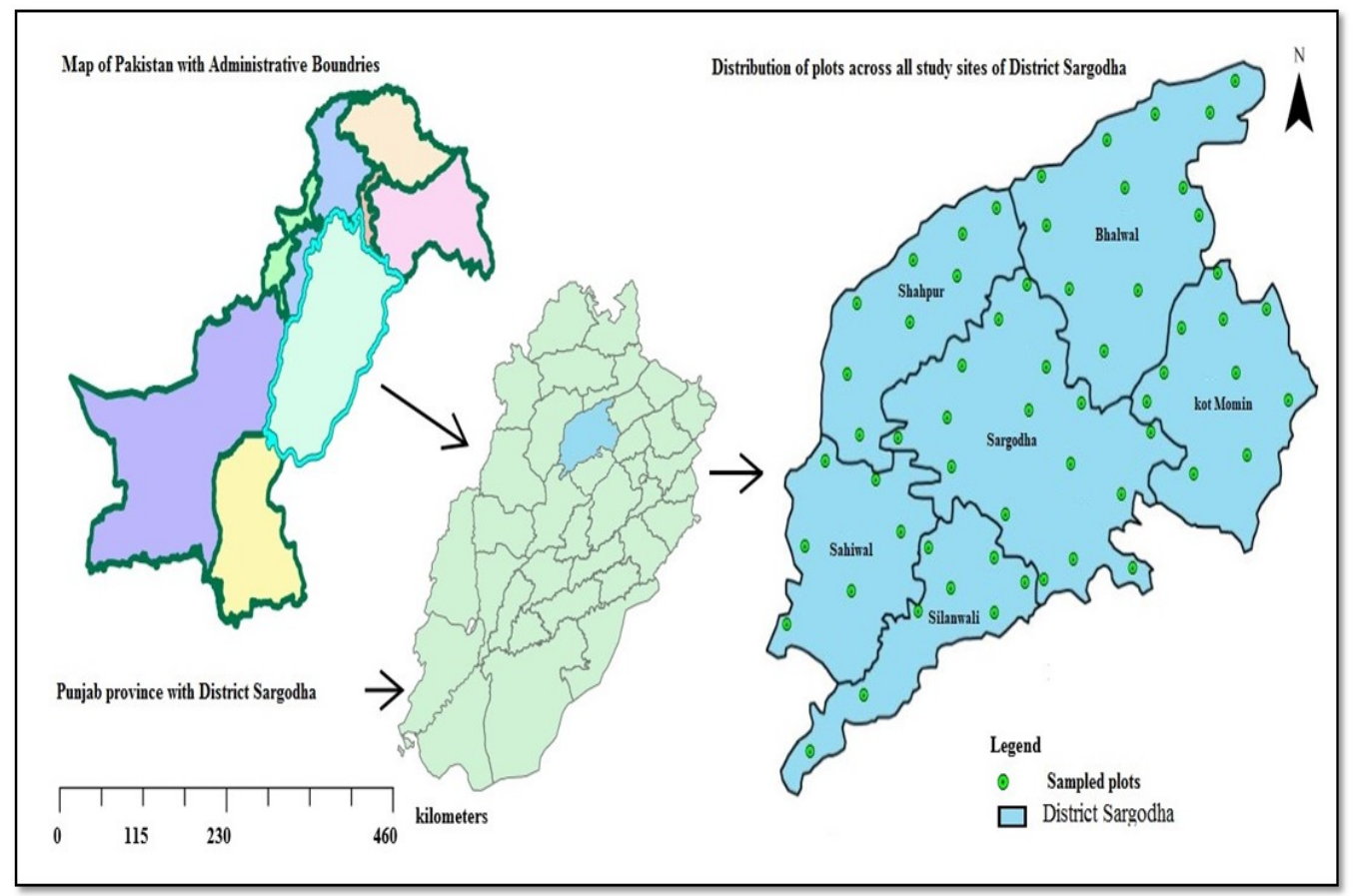

Figure 1. Map showing study sites with the distribution of sampling points of the citrus-based intercropping system in district Sargodha.

\subsection{Tree Biomass and Carbon Estimation}

For the collection of inventory data, field visits were carried out from April 2016 to August 2016. Sampling was performed in each citrus orchard ( 0.405 ha) by considering the method described by Pearson et al. [27]. An area of $20 \mathrm{~m} \times 20 \mathrm{~m}$ was sampled from each plot. The stem basal diameter and height of each tree in the sampling plots were measured. The diameter was recorded at $30 \mathrm{~cm}$ above the ground to avoid grafted stem and tree forking at $130 \mathrm{~cm}$. For trees with two or more branches below $30 \mathrm{~cm}$, the basal diameter was measured individually, and an equivalent diameter was calculated at the end. Tree age ranged from 4 to 18 years of measured plots across the whole study area. Tree basal area for individual trees and plot was also computed from the measured basal diameter. Above-ground biomass $\mathrm{kg}$ per plot of citrus trees was assessed by different allometric equations converted to $\mathrm{Mg} \mathrm{ha}^{-1}[28,29]$. The results obtained from three equations were then averaged to increase the precision. Below-ground biomass was calculated by dividing the above-ground biomass by $0.24[30,31]$. The carbon stock per plot was estimated by multiplying the biomass by 0.48 [32].

\subsection{Soil Sampling and Analysis}

Samples of soil were taken randomly with the help of a soil auger from 10 plots of each site at two depths: $0-15 \mathrm{~cm}$ and $15-30 \mathrm{~cm}$ depths. Across all study sites, soil samples were obtained from three points in each plot, and a combined sample was made for each depth. Overall, 120 samples for both depths were taken from the whole study area. After collection, these samples of the same site and depth were separated and air-dried [33]. Soil 
bulk density was computed by the metal core of dimension $4 \times 5 \mathrm{~cm}$ at both depths. All the soil samples were ground first and then sieved through a $0.25 \mathrm{~mm}$ sieve to determine the organic carbon. The wet oxidation method described by Walkley and Black [34] was used to estimate the organic carbon. Finally, the soil carbon contents per hectare for each depth was computed as follows

$$
\text { Soil carbon stock }=\text { OC } \% \times \text { Bulk density }\left(\mathrm{g} \mathrm{cm}^{-3}\right) \times \text { sampling depth }(\mathrm{cm})
$$

\subsection{Statistical Analysis}

Descriptive statistics were performed by using Statistics 8.1 statistical software package. Means of all the parameters were compared by one-way ANOVA, followed by the LSD method to test the difference across all study sites.

\section{Results and Discussion}

\subsection{Citrus Biomass and Carbon Stock}

The basal diameter and height of citrus trees showed some variations among study sites in district Sargodha (Table 1). However, the difference in inventory parameters across all study sites was not significant $(p>0.05)$. The total biomass production of citrus trees ranged from $14.55 \mathrm{Mg} \mathrm{ha}^{-1}$ to $21.43 \mathrm{Mg} \mathrm{ha}^{-1}$ across six study sites with maximum accumulation at Shahpur and minimum at Sahiwal. The above and below-ground biomass accumulation varied significantly $(p \leq 0.05)$, and the distribution status of biomass amongst study sites was in the order of Shahpur $>$ Sargodha $>$ Silanwali $>$ Bhalwal $>$ Kot Momin $>$ Sahiwal (Table 2). Based on biomass production, the above and below-ground carbon storage of citrus-based agroforestry system among all study sites was significantly different $(p \leq 0.05)$. Overall, the ranking of carbon storage in the citrus intercropping system among study sites was in the order of Shahpur (10.28 $\left.\mathrm{Mg} \mathrm{C} \mathrm{ha}^{-1}\right)>\operatorname{Sargodha}\left(9.69 \mathrm{Mg} \mathrm{C} \mathrm{ha}^{-1}\right)$ $>$ Silanwali (8.65 Mg C ha $\left.{ }^{-1}\right)>$ Bhalwal $\left(8.43 \mathrm{Mg} \mathrm{C} \mathrm{ha}^{-1}\right)>\operatorname{Kot}$ Momin $\left(7.77 \mathrm{Mg} \mathrm{C} \mathrm{ha}^{-1}\right)$ $>$ Sahiwal (6.98 $\mathrm{Mg} \mathrm{C} \mathrm{ha}^{-1}$ ), (Figure 2). The carbon stock in Shahpur was 6.08\%, 18.84\%, $21.80 \%, 32.30 \%$ and $47.27 \%$ higher than that in Sargodha, Silanwali, Bhalwal, Kot Momin, and Sahiwal, respectively. The estimated basal area per plot showed a strong and positive linear relationship $\left(\mathrm{R}^{2}=0.91, p \leq 0.05\right)$ with total citrus carbon stock in the complete inventory plots of the study area (Figure 3).

Table 1. Growth parameters of the citrus-based intercropping system in district Sargodha.

\begin{tabular}{cccc}
\hline Study Sites & \# Plots $\mathbf{( 0 . 4 0 5}$ ha) & Basal Diameter (cm) & Height (m) \\
\hline Bhalwal & 60 & $13.21 \pm 3.01$ & $3.92 \pm 0.71$ \\
Kot Momin & 50 & $11.75 \pm 2.54$ & $3.34 \pm 1.26$ \\
Sahiwal & 30 & $10.67 \pm 2.09$ & $3.13 \pm 0.59$ \\
Sargodha & 80 & $13.42 \pm 2.70$ & $3.59 \pm 0.98$ \\
Shahpur & 40 & $13.97 \pm 2.39$ & $4.03 \pm 0.71$ \\
Silanwali & 40 & $12.64 \pm 1.61$ & $3.37 \pm 0.51$ \\
\hline
\end{tabular}

Values are means \pm standard deviation.

Table 2. Biomass production estimation of a citrus-based intercropping system in district Sargodha.

\begin{tabular}{|c|c|c|c|}
\hline Study Sites & $\begin{array}{l}\text { Above-Ground Biomass } \\
\left(\mathrm{Mg} \mathrm{ha}^{-1}\right)\end{array}$ & $\begin{array}{c}\text { Below-Ground Biomass } \\
\left(\mathrm{Mg} \mathrm{ha}^{-1}\right)\end{array}$ & $\begin{array}{l}\text { Total Biomass } \\
\left(\mathrm{Mg} \mathrm{ha}^{-1}\right)\end{array}$ \\
\hline Bhalwal & $14.06^{\mathrm{b}} \pm 2.62$ & $3.52^{c} \pm 0.65$ & $17.58^{\mathrm{cd}} \pm 3.27$ \\
\hline Kot Momin & $12.94^{b c} \pm 3.51$ & $3.27^{c} \pm 0.87$ & $16.21^{\mathrm{cd}} \pm 4.39$ \\
\hline Sahiwal & $11.48^{c} \pm 1.35$ & $3.07^{c} \pm 0.35$ & $14.55^{\mathrm{d}} \pm 1.70$ \\
\hline Sargodha & $16.14^{\mathrm{a}} \pm 2.61$ & $4.04^{b} \pm 0.66$ & $20.18^{a b} \pm 3.26$ \\
\hline Shahpur & $16.61^{\mathrm{a}} \pm 1.85$ & $4.82^{\mathrm{a}} \pm 0.77$ & $21.43^{\mathrm{a}} \pm 2.42$ \\
\hline Silanwali & $14.42^{\mathrm{ab}} \pm 1.76$ & $3.60 b^{c} \pm 0.44$ & $18.02^{b c} \pm 2.19$ \\
\hline
\end{tabular}

Values are means \pm standard deviation; means followed by different letters are significantly different at $5 \%$ probability level. 


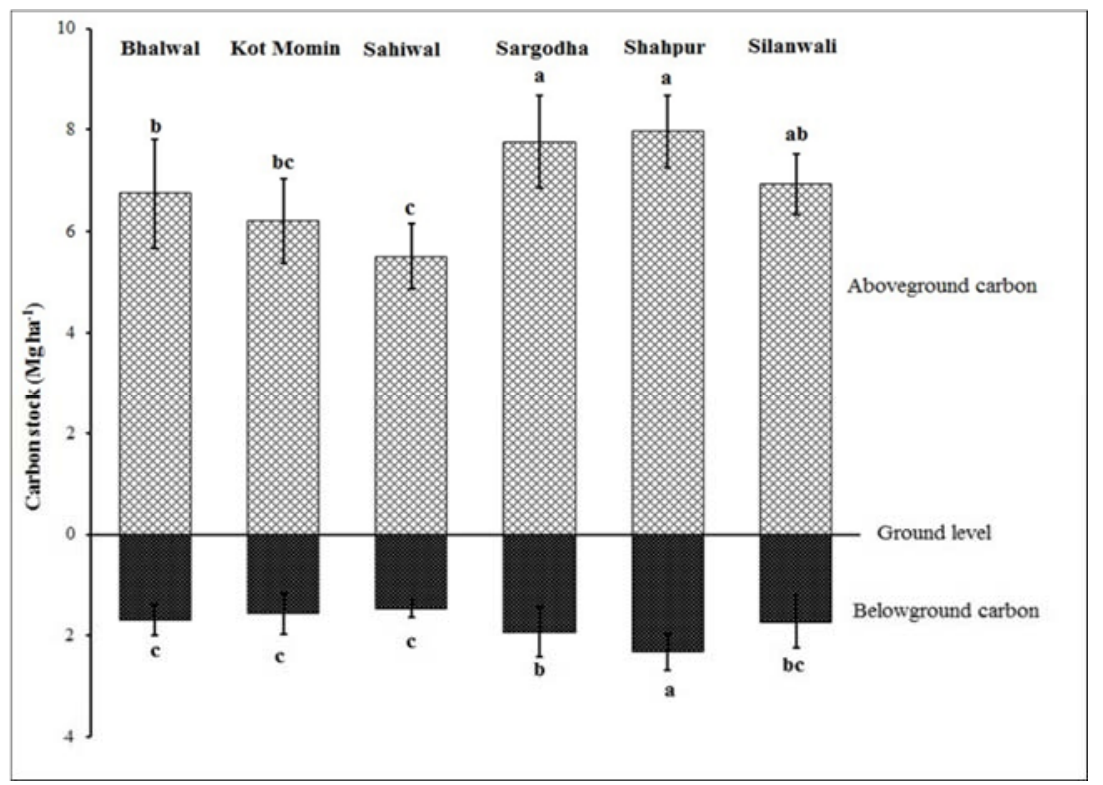

Figure 2. Carbon stock concentration $\left(\mathrm{Mg} \mathrm{ha}^{-1}\right)$ in the citrus-based agroforestry system above- and below-ground parts. a-c represents the standard errors.

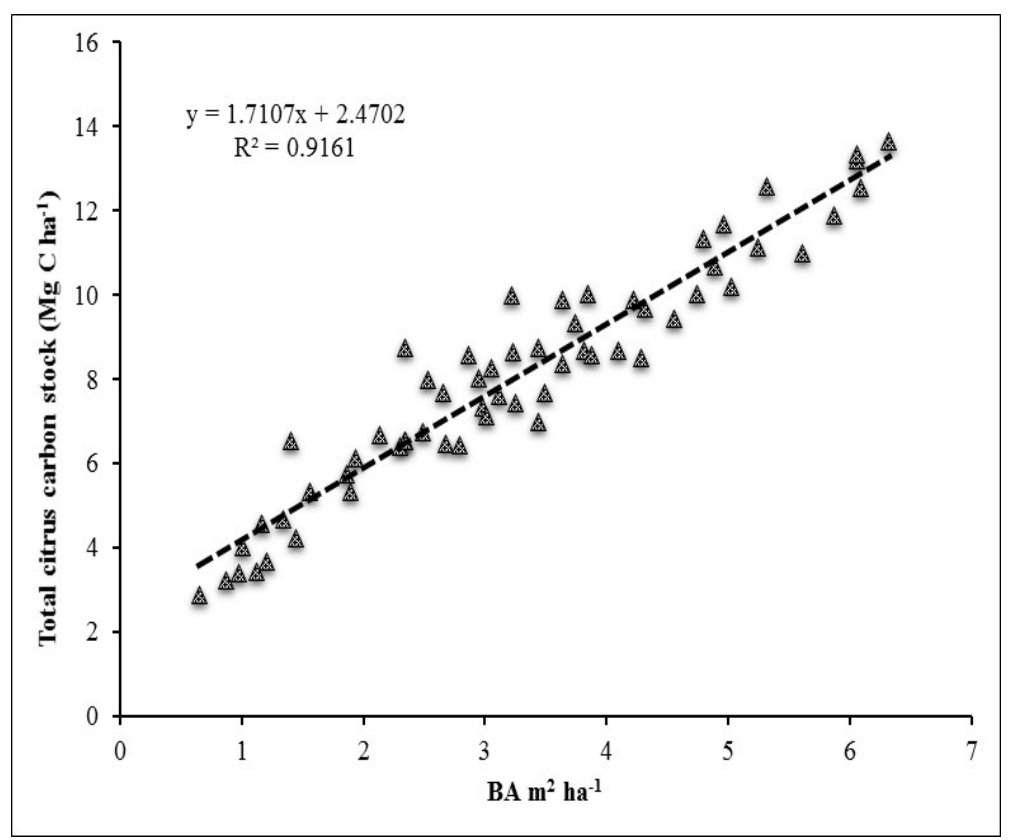

Figure 3. Correlation between citrus total carbon stock $\left(\mathrm{Mg} \mathrm{C} \mathrm{ha}^{-1}\right)$ and basal area $\left(\mathrm{m}^{2} \mathrm{ha}^{-1}\right)$ in whole plots of study sites.

In contrast to other tree species, there is some specific feature of the citrus-based agroforestry system concerning carbon-capturing ability to combat climate change. Because of their particular physiological features, evergreen plants like citrus play an important role in fixing atmospheric carbon [1], as earlier studies have demonstrated that citrus plants could be a suitable option for combating climate change on a sustained basis $[18,21,35]$. Moreover, trees are known as a vital part of biomass accumulation in agroforestry systems. Total plant biomass and carbon accumulation showed little variation among all sites, highest in Shahpur and Sargodha and lowest in Sahiwal. Total biomass in a citrus-based intercropping system varied between 14.55 and $21.43 \mathrm{Mg} \mathrm{ha}^{-1}$ in the current study. This variation of tree biomass between the sites is due to the difference between age, size, the density of 
trees along with management practices in the area as articulated by Ramachandran Nair, Mohan Kumar, and Nair [14]; Liu et al. [36]; Dash and Behera [37]. For instance, Shahpur has a greater biomass accumulation due to higher basal diameter and height than all other sites. This might be endorsed to a slight difference in climatic conditions along with awareness of agroforestry management practices across the study area. Similarly, Yadav, Bisht, and Pandey [21] and Yadav, Gupta, Bhutia, Bisht, Pattanayak, Meena, Choudhary, and Tiwari [10] have described similar differences in biomass accumulation in different fruit-based agroforestry systems. Like biomass, carbon concentration in a system is directly determined by several factors: environmental and socioeconomic and largely depends on the structure and function of the system $[9,38]$. The establishment of trees on farmlands enhances carbon sequestration ability both in soil and vegetation [39]. The above and below ground carbon stock of the current studied system ranged from 5.51 to $7.97 \mathrm{Mg} \mathrm{C}^{-1}$ \& 1.47 to $2.31 \mathrm{Mg} \mathrm{C} \mathrm{ha}^{-1}$, respectively, among all sites of district Sargodha. Likewise, biomass, these small variations among carbon stocks are again dependent on the quality of the site, soil type, growth pattern of citrus trees on each site, age of trees, management practices in the area in combination with their relation to below-ground components of the system [37,40]. Similar trends of biomass carbon accumulation have been reported in various fruit-based agroforestry systems, especially in Indian Himalaya, e.g., Yadav, Bisht, and Pandey [21] have described the above-ground carbon accumulation $\left(8.4 \mathrm{Mg} \mathrm{Cha}^{-1}\right)$ in the lemon + wheat system, a slightly greater than those presented in this study.

\subsection{Soil Carbon Density}

Organic carbon contents, bulk density, and soil carbon stock in the same soil depth varied among all study sites of the citrus intercropping system, and this difference was significant for both soil depths: $0-15$ and $15-30 \mathrm{~cm}$ (Table 3). At surface soil: 0-15 cm, among six study sites, the maximum soil carbon concentration (0.58\%) was computed in Sargodha and the lowest $(0.44 \%)$ in Silanwali $(p \leq 0.05)$. At $15-30 \mathrm{~cm}$ soil depth, Shahpur $(0.52 \%)$ and Sargodha $(0.49 \%)$ have significantly greater soil carbon contents than other study sites. The maximum values of soil bulk density were computed in Silanwali $\left(1.49 \& 1.55 \mathrm{~g} \mathrm{~cm}^{-3}\right)$, followed by Shahpur $\left(1.47 \& 1.54 \mathrm{~g} \mathrm{~cm}^{-3}\right)$ and Sargodha $\left(1.42 \& 1.51 \mathrm{~g} \mathrm{~cm}^{-3}\right)$, which were significantly higher as compared to the other three sites: Bhalwal, Kot Momin and Sahiwal, respectively $(p \leq 0.05)$. Due to soil pore space filled with eroded soil, porosity is reduced, and bulk density increases. Similar to carbon concentration and soil bulk density, there was some variation in the soil carbon stock between the study sites of district Sargodha. A higher amount of soil carbon was recorded in surface soil $(0-15 \mathrm{~cm})$ for all study sites than 15-30 cm soil layer. At 0-15 cm depth, soil carbon stock ranged from $9.42 \mathrm{MgC} \mathrm{ha}^{-1}$ to $12.43 \mathrm{Mg} \mathrm{C} \mathrm{ha}^{-1}$ across all study sites whereas, at $15-30 \mathrm{~cm}$ depth, higher soil carbon stock $\left(12.06 \mathrm{Mg} \mathrm{C} \mathrm{ha}^{-1}\right)$ was observed in Shahpur and was significantly different $(p \leq 0.05)$ from all other sites. Overall, total soil carbon stock was greater in Shahpur $\left(24.21 \mathrm{Mg} \mathrm{Cha}^{-1}\right)$ and Sargodha (23.65 Mg C ha-1) as compared to other study sites at 0-30 $\mathrm{cm}$ depth (Table 4).

Table 3. Biomass production estimation of a citrus-based intercropping system in district Sargodha.

\begin{tabular}{|c|c|c|c|}
\hline Study Sites & $\begin{array}{l}\text { Above-Ground Biomass } \\
\left(\mathrm{Mg} \mathrm{ha}^{-1}\right)\end{array}$ & $\begin{array}{l}\text { Below-Ground Biomass } \\
\left(\mathrm{Mg} \mathrm{ha}^{-1}\right)\end{array}$ & $\begin{array}{l}\text { Total Biomass } \\
\left(\mathrm{Mg} \mathrm{ha}^{-1}\right)\end{array}$ \\
\hline Bhalwal & $14.06^{\mathrm{b}} \pm 2.62$ & $3.52^{c} \pm 0.65$ & $17.58^{\mathrm{cd}} \pm 3.27$ \\
\hline Kot Momin & $12.94^{\mathrm{bc}} \pm 3.51$ & $3.27^{\mathrm{c}} \pm 0.87$ & $16.21^{\mathrm{cd}} \pm 4.39$ \\
\hline Sahiwal & $11.48^{\mathrm{c}} \pm 1.35$ & $3.07^{\mathrm{c}} \pm 0.35$ & $14.55^{\mathrm{d}} \pm 1.70$ \\
\hline Sargodha & $16.14^{\mathrm{a}} \pm 2.61$ & $4.04^{b} \pm 0.66$ & $20.18^{\mathrm{ab}} \pm 3.26$ \\
\hline Shahpur & $16.6^{\mathrm{a}} \pm 1.85$ & $4.82^{a} \pm 0.77$ & $21.43^{\mathrm{a}} \pm 2.42$ \\
\hline Silanwali & $14.42^{\mathrm{ab}} \pm 1.76$ & $3.60 b^{c} \pm 0.44$ & $18.02^{b c} \pm 2.19$ \\
\hline
\end{tabular}

Values are means \pm standard deviation; means followed by different letters are significantly different at $5 \%$ probability level. 
Table 4. Soil organic carbon, bulk density, and soil carbon stock of citrus-based intercropping system in district Sargodha.

\begin{tabular}{|c|c|c|c|c|c|c|}
\hline \multirow{2}{*}{ Study Sites } & \multicolumn{2}{|c|}{ Organic Carbon (\%) } & \multicolumn{2}{|c|}{ Bulk Density $\left(\mathrm{g} \mathrm{cm}^{-3}\right)$} & \multicolumn{2}{|c|}{ Soil Carbon Stock (Mg ha $\left.{ }^{-1}\right)$} \\
\hline & $0-15 \mathrm{~cm}$ & $15-30 \mathrm{~cm}$ & $0-15 \mathrm{~cm}$ & $15-30 \mathrm{~cm}$ & $0-15 \mathrm{~cm}$ & $15-30 \mathrm{~cm}$ \\
\hline Bhalwal & $0.53^{b} \pm 0.05$ & $0.47^{\mathrm{ab}} \pm 0.04$ & $1.39^{\mathrm{cd}} \pm 0.04$ & $1.46^{\mathrm{b}} \pm 0.05$ & $11.28^{b} \pm 1.04$ & $10.33^{b c} \pm 1.03$ \\
\hline Kot Momin & $0.50^{b c} \pm 0.04$ & $0.42^{b c} \pm 0.05$ & $1.34^{\mathrm{d}} \pm 0.03$ & $1.39^{c} \pm 0.06$ & $10.13^{c} \pm 1.03$ & $8.93^{\mathrm{d}} \pm 1.54$ \\
\hline Sahiwal & $0.46^{\mathrm{cd}} \pm 0.06$ & $0.39^{c} \pm 0.05$ & $1.35^{\mathrm{d}} \pm 0.03$ & $1.43^{b c} \pm 0.05$ & $9.42^{\mathrm{c}} \pm 1.11$ & $8.60^{\mathrm{d}} \pm 1.19$ \\
\hline Sargodha & $0.58^{a} \pm 0.05$ & $0.49^{\mathrm{a}} \pm 0.07$ & $1.42^{b c} \pm 0.07$ & $1.51^{\mathrm{a}} \pm 0.06$ & $12.43^{\mathrm{a}} \pm 1.19$ & $11.21^{\mathrm{ab}} \pm 1.74$ \\
\hline Shahpur & $0.54^{\mathrm{ab}} \pm 0.02$ & $0.52^{\mathrm{a}} \pm 0.04$ & $1.47^{\mathrm{ab}} \pm 0.07$ & $1.54^{\mathrm{a}} \pm 0.09$ & $12.14^{\mathrm{ab}} \pm 0.94$ & $12.06^{\mathrm{a}} \pm 1.26$ \\
\hline Silanwali & $0.44^{\mathrm{d}} \pm 0.07$ & $0.40^{c} \pm 0.06$ & $1.49^{\mathrm{a}} \pm 0.06$ & $1.55^{\mathrm{a}} \pm 0.05$ & $9.81^{\mathrm{c}} \pm 1.48$ & $9.49^{\mathrm{cd}} \pm 1.35$ \\
\hline
\end{tabular}

Values are means \pm standard deviation; means followed by different letters are significantly different at $5 \%$ probability level.

Soil carbon stock is considered an important carbon pool in measuring carbon balance in different biomes throughout the globe [41]. The major factor of maximum total carbon loss to the atmosphere from agroecosystems is soil respiration. Soil respiration is highly variable in several plant species depending upon plant age, growth habits, and climatic conditions [16]. The present study's overall range of soil carbon stocks $(0-30 \mathrm{~cm})$ was 25.07 and $34.50 \mathrm{Mg} \mathrm{C} \mathrm{ha}^{-1}$ between all study sites. The estimates of our study showed that soil carbon stocks among sites were more or less similar to those estimated in other citrusbased land-use systems [1,34]. However, Yadav, Gupta, Bhutia, Bisht, Pattanayak, Meena, Choudhary, and Tiwari [10] estimated soil carbon density between 54.9 to $59.5 \mathrm{t} \mathrm{C} \mathrm{ha}^{-1}$ in four agroforestry-based land-use systems (agrisilviculture, agrihorticulture, agrihortisilviculture, and agrisilvihorticulture, etc.) in Indian Himalaya was higher than our estimates. These variations might be because of the differences with regard to space and time in physical components of the plants and their management. The higher concentration of soil carbon in various agroecosystems is associated with a greater amount of biomass reverted to soil resulting in higher soil organic matter stabilization and lower decomposition rates [42]. Apart from this, other factors, such as soil type and age, greatly affect and adjust the soil carbon amount in agroforestry land-use systems [43,44].

\subsection{Total Carbon Stock (Biomass + Soil) of System}

An overview of the findings (Table 5) indicates that the total carbon stock (biomass carbon + soil carbon) of the citrus intercropping system varied significantly across the study sites $(p \leq 0.05)$. The maximum total carbon density was computed in Shahpur (34.50 Mg C ha ${ }^{-1}$ ), followed by Sargodha (33.34 Mg C ha-1), and was significantly higher as compared to other sites, while minimum $\left(25.07 \mathrm{Mg} \mathrm{C}^{-1}\right)$ total carbon storage was computed in Sahiwal $(p \leq 0.05)$. In Shahpur, the total carbon stock was $14.80 \%, 23.39 \%$, $28.53 \%$ and $37.61 \%$ was higher when compared with Bhalwal, Silanwali, Kot Momin, and Sahiwal, respectively. Our findings illustrated that the soil carbon pool was prominent in the system's total carbon stock. Similar findings regarding total carbon storage have also been described $[21,45]$ in different agroforestry systems. Likewise, Yasin, Nawaz, Siddiqui, and Niazi [9] and Nawaz, Shah, Gul, Afzal, Ahmad and Ghaffar [30] reported a similar range of total carbon stock in P. deltoides based bund planted agroforestry systems under semi-arid conditions and E. camaldulensis based agroforestry system under arid conditions on marginal lands. However, the total carbon stock in the agrisilvihorticulture system in Indian Himalayas was much greater $\left(93 \mathrm{tC} \mathrm{ha}^{-1}\right)$ than our estimates [10]. Similarly, the present estimates are far below the estimates (12-228 $\mathrm{Mg} \mathrm{C} \mathrm{ha}^{-1}$ ) of Krankina and Harmon [46] for agrisilvicultre systems of humid tropical regions of Southeast Asia and in different land uses varying from 51 to $448 \mathrm{t} \mathrm{C} \mathrm{ha}^{-1}$ in Ethiopia [47]. However, the total carbon stocks of the present study are greater than the estimates (15-18 $\mathrm{Mg} \mathrm{C} \mathrm{ha}^{-1}$ ) of Winjum et al. [48] for silvopastoral systems of low humid tropical regions of northern Asia. 
Table 5. Total carbon stock (biomass + soil) of a citrus-based intercropping system in district Sargodha.

\begin{tabular}{|c|c|c|c|}
\hline Sampling Sites & $\begin{array}{c}\text { Total Biomass Carbon } \\
\left(\mathrm{Mg} \mathrm{C} \mathrm{ha}^{-1}\right)\end{array}$ & $\begin{array}{l}\text { Total Soil Carbon (Mg C } \\
\left.\qquad \mathrm{ha}^{-1}\right)\end{array}$ & $\begin{array}{l}\text { Total Carbon Stock } \\
\quad\left(\mathrm{Mg} \mathrm{C} \mathrm{ha}^{-1}\right)\end{array}$ \\
\hline Bhalwal & $8.43^{\mathrm{cd}} \pm 1.57$ & $21.61^{b} \pm 1.64$ & $30.05^{b} \pm 1.62$ \\
\hline Kot Momin & $7.78^{\mathrm{cd}} \pm 2.10$ & $19.06^{\mathrm{c}} \pm 1.62$ & $26.84^{\mathrm{cd}} \pm 2.52$ \\
\hline Sahiwal & $6.98^{d} \pm 0.76$ & $18.02^{\mathrm{c}} \pm 1.78$ & $25.07^{\mathrm{d}} \pm 1.37$ \\
\hline Sargodha & $9.68^{a b} \pm 1.56$ & $23.65^{\mathrm{a}} \pm 2.23$ & $33.34^{\mathrm{a}} \pm 2.80$ \\
\hline Shahpur & $10.28^{a} \pm 1.16$ & $24.21^{\mathrm{a}} \pm 1.24$ & $34.50^{\mathrm{a}} \pm 2.08$ \\
\hline Silanwali & $8.65^{b c} \pm 1.05$ & $19.31^{\mathrm{c}} \pm 1.97$ & $27.96^{\mathrm{c}} \pm 2.02$ \\
\hline
\end{tabular}

Values are means \pm standard deviation; means followed by different letters are significantly different at $5 \%$ probability level.

\section{Conclusions}

Citrus reticulata is widely interplanted across district Sargodha on a commercial basis. We concluded that the citrus-based planting showed a remarkable amount of carbon storage in tree biomass and soil. The system total carbon stocks varied across study sites due to differences among age, growth pattern of citrus trees, and their management across the study area. Thus, the ability and potential of fruit-based agroforestry systems make them a viable option to cope with climate change by sequestering a reasonable concentration of $\mathrm{CO}_{2}$ from the atmosphere. Apart from this, these agroforestry systems provide livelihood security to local dwellers, especially in underdeveloped countries. Our findings suggest that the authorities promote such agroforestry systems to improve environmental services and increase farmers' income.

Author Contributions: Conceptualization, G.Y., S.U.R. and Z.D.; Data curation, I.Q., A.R.S., M.I., S.G., M.A.B. and A.R.; Formal analysis, G.Y., M.Z., I.Q., A.R.S., S.G., M.A.B. and A.R.; Funding acquisition, S.U.R. and Z.D.; Investigation, G.Y., M.Z., I.Q., A.R.S. and S.G.; Methodology, G.Y. and M.F.N.; Resources, M.F.N., A.R.S., M.I., S.G., M.A.B. and A.R.; Software, A.R.S., M.I., S.G. and M.A.B.; Supervision, A.R. and S.U.R.; Validation, S.U.R. and Z.D.; Visualization, A.R. and S.U.R.; Writingreview \& editing, A.R.S., M.I., A.R. and S.U.R. All authors have read and agreed to the published version of the manuscript.

Funding: The authors are grateful to the funding agency (HEC) for providing the necessary funds and facilities to complete this study under NRPU Project \#2459. The authors are also grateful to the National Natural Science Foundation of China (51779260), Henan province Key Point Research and Invention Program (192102110051), the Technical Innovation Program of the Chinese Academy of Agricultural Sciences Grant NO. ASTIP202101.

Institutional Review Board Statement: Not applicable.

Informed Consent Statement: Not applicable.

Data Availability Statement: All data required to support this research is already presented in this manuscript.

Acknowledgments: The authors are grateful to the funding agency (HEC) for providing the necessary funds and facilities to complete this study under NRPU Project \#2459.

Conflicts of Interest: Authors declare that there is no conflict of interest.

\section{References}

1. Iglesias, D.J.; Quinones, A.; Font, A.; Martínez-Alcántara, B.; Forner-Giner, M.Á.; Legaz, F.; Primo-Millo, E. Carbon balance of citrus plantations in Eastern Spain. Agric. Ecosyst. Environ. 2013, 171, 103-111. [CrossRef]

2. Kumar, K.K.; Nagai, M.; Witayangkurn, A.; Kritiyutanant, K.; Nakamura, S. Above Ground Biomass Assessment from Combined Optical and SAR Remote Sensing Data in Surat Thani Province, Thailand. J. Geogr. Inf. Syst. 2016, 08, 506-516. [CrossRef]

3. Stocker, T. Climate Change 2013: The Physical Science Basis: Working Group I Contribution to the Fifth Assessment Report of the Intergovernmental Panel on Climate Change; Cambridge University Press: Cambridge, UK, 2014. 
4. Parry, M.; Parry, M.L.; Canziani, O.; Palutikof, J.; Van der Linden, P.; Hanson, C. Climate Change 2007-Impacts, Adaptation and Vulnerability: Working Group II Contribution to the Fourth Assessment Report of the IPCC; Cambridge University Press: Cambridge, UK, 2007; Volume 4.

5. Chavan, B.; Rasal, G. Potentiality of Carbon Sequestration in six year ages young plant from University campus of Aurangabad. Glob. J. Res. Eng. 2011, 11, 7-C.

6. Victor, A.D.; Valery, N.N.; Louis, Z.; Aimé, V.B.T.; Aliou, S. Carbon Sequestration Potential and Economic Value in Agroforestry Parkland to Tectona grandis L. f.(Verbenaceae) in Central Africa: A Case Study to Department of Poli (Northern Region in Cameroon). Adv. Res. 2019, 8, 1-16. [CrossRef]

7. Chave, J.; Andalo, C.; Brown, S.; Cairns, M.A.; Chambers, J.; Eamus, D.; Fölster, H.; Fromard, F.; Higuchi, N.; Kira, T.; et al. Tree allometry and improved estimation of carbon stocks and balance in tropical forests. Oecologia 2005, 145, 87-99. [CrossRef]

8. Yadav, R.P.; Gupta, B.; Bhutia, P.L.; Bisht, J.K. Socioeconomics and sources of livelihood security in Central Himalaya, India: A case study. Int. J. Sustain. Dev. World Ecol. 2017, 24, 545-553. [CrossRef]

9. Yasin, G.; Nawaz, M.; Siddiqui, M.; Niazi, N. Biomass, carbon stocks and CO2 sequestration in three different aged irrigated populus deltoides bartr. Ex marsh. Bund planting agroforestry systems. Appl. Ecol. Environ. Res. 2018, 16, 6239-6252. [CrossRef]

10. Yadav, R.P.; Gupta, B.; Bhutia, P.L.; Bisht, J.K.; Pattanayak, A.; Meena, V.S.; Choudhary, M.; Tiwari, P. Biomass and carbon budgeting of sustainable agroforestry systems as ecosystem service in Indian Himalayas. Int. J. Sustain. Dev. World Ecol. 2019, 26, 460-470. [CrossRef]

11. Raj, A.; Jhariya, M.K.; Pithoura, F. Need of agroforestry and impact on ecosystem. J. Plant Dev. Sci. Es 2014, 6, 577-581.

12. Nawaz, M.; Yousaf, M.; Yasin, G.; Gul, S.; Ahmed, I.; Abdullah, M.; Rafay, M.; Tanvir, M.; Asif, M.; Afzal, S. Agroforestry status and its role to sequester atmospheric $\mathrm{CO}_{2}$ under semi-arid climatic conditions in Pakistan. Appl. Ecol. Environ. Res. 2018, 16, 645-661. [CrossRef]

13. Mohan Kumar, B.; Ramachandran Nair, P. Carbon Sequestration Potential of Agroforestry Systems; Springer: Berlin, Germany, 2011.

14. Nair, P.K.R.; Kumar, B.M.; Nair, V.D. Agroforestry as a strategy for carbon sequestration. J. Plant Nutr. Soil Sci. 2009, 172, 10-23. [CrossRef]

15. Qubaja, R.; Yang, F.; Amer, M.; Tatarinov, F.; Yakir, D. Ecophysiology of an urban citrus orchard. Urban For. Urban Green. 2021, 65, 127361. [CrossRef]

16. Yixiang, W.A.N.G.; Boqi, W.E.N.G.; Na, T.I.A.N.; Zhong, Z.; Mingkuang, W.A.N.G. Soil organic carbon stocks of citrus orchards in Yongchun county, Fujian Province, China. Pedosphere 2017, 27, 985-990.

17. Xiaolian, W.; Yueqing, C.; Youjin, L.; Xia, C.; Yonghong, X. Carbon sequestration and storage of citrus orchard system in Three Gorges Reservoir region of Chongqing, Southwest China. J. Agric. Sci. 2014, 27, 693-698.

18. Liguori, G.; Gugliuzza, G.; Inglese, P. Evaluating carbon fluxes in orange orchards in relation to planting density. J. Agric. Sci. 2009, 147, 637-645. [CrossRef]

19. Iglesias, D.J.; Lliso, I.; Tadeo, F.R.; Talon, M. Regulation of photosynthesis through source: Sink imbalance in citrus is mediated by carbohydrate content in leaves. Physiol. Plant. 2002, 116, 563-572. [CrossRef]

20. Marti, B.V.; Estornell, J.; Cortés, I.L.; Martí-Gavilá, J. Calculation of biomass volume of citrus trees from an adapted dendrometry. Biosyst. Eng. 2012, 112, 285-292. [CrossRef]

21. Yadav, R.; Bisht, J.K.; Pandey, B.M. Above ground biomass and carbon stock of fruit tree based land use systems in Indian Himalaya. Ecoscan 2015, 9, 779-783.

22. Sharif, M.; Farooq, U.; Malik, W.; Bashir, M. Citrus Marketing in Punjab: Constraints and Potential for Improvement [with Comments]. Pak. Dev. Rev. 2005, 44, 673-694. [CrossRef]

23. Usman, M.; Ashraf, I.; Chaudhary, K.M.; Talib, U. Factors impeding citrus supply chain in Central Punjab, Pakistan. Int. J. Agric. Ext. 2018, 6, 01-05. [CrossRef]

24. Segura, M.; Kanninen, M.; Suárez, D. Allometric models for estimating above-ground biomass of shade trees and coffee bushes grown together. Agrofor. Syst. 2006, 68, 143-150. [CrossRef]

25. Akram, B.; Abbas, F.; Ibrahim, M.; Nawaz, M.; Zahra, S.; Salik, M.; Hammad, H. Above-ground carbon pools of citrus acreage in Pakistan. JAPS J. Anim. Plant Sci. 2017, 27, 1903-1908.

26. Mobeen, M.; Ahmed, H.; Ullah, F.; Riaz, M.O.; Mustafa, I.; Khan, M.R.; Hanif, M.U.; Muhammad, M. Impact of climate change on the precipitation pattern of district Sargodha, Pakistan. Int. J. Clim. Chang. Strat. Manag. 2017, 9, 21-35. [CrossRef]

27. Pearson, T.; Walker, S.; Brown, S. Sourcebook for Land Use, Land-Use Change and Forestry Projects. 2013. Available online: http:/ /hdl.handle.net/10986/16491 (accessed on 10 October 2021).

28. Schroth, G.; D'Angelo, S.A.; Teixeira, W.G.; Haag, D.; Lieberei, R. Conversion of secondary forest into agroforestry and monoculture plantations in Amazonia: Consequences for biomass, litter and soil carbon stocks after 7 years. For. Ecol. Manag. 2002, 163, 131-150. [CrossRef]

29. Brown, S. Estimating Biomass and Biomass Change of Tropical Forests: A Primer; Food \& Agriculture Org.: Roma, Italy, 1997 ; Volume 134.

30. Mehta, L.C.; Singh, J.; Chauhan, P.S.; Singh, B.; Manhas, R.K. Biomass accumulation and carbon storage in six-year old Citrus reticulata Blanco plantation. Indian For. 2016, 142, 563-568.

31. Nawaz, M.F.; Shah, S.A.A.; Gul, S.; Afzal, S.; Ahmad, I.; Ghaffar, A. Carbon sequestration and production of Eucalyp-tus camaldulensis plantations on marginal sandy agricultural lands. Pak. J. Agric. Sci. 2017, 54, 335-342.

32. Thomas, S.C.; Martin, A.R. Carbon Content of Tree Tissues: A Synthesis. Forests 2012, 3, 332-352. [CrossRef] 
33. Arora, G.; Chaturvedi, S.; Kaushal, R.; Nain, A.; Tewari, S.; ALAM, N.M.; Chaturvedi, O.P. Growth, biomass, carbon stocks, and sequestration in an age series of Populus deltoides plantations in Tarai region of central Himalaya. Turk. J. Agric. For. 2014, 38, 550-560. [CrossRef]

34. Walkley, A.; Black, I.A. An examination of the Degtjareff method for determining soil organic matter, and a proposed modification of the chromic acid titration method. Soil Sci. 1934, 37, 29-38. [CrossRef]

35. Gratani, L.; Varone, L.; Catoni, R. Relationship between net photosynthesis and leaf respiration in Mediterranean ever-green species. Photosynthetica 2008, 46, 567-573. [CrossRef]

36. Liu, Z.-W.; Chen, R.-S.; Song, Y.-X.; Han, C.-T. Above-ground biomass and water storage allocation in alpine willow shrubs in the Qilian Mountains in China. J. Mt. Sci. 2015, 12, 207-217. [CrossRef]

37. Dash, M.C.; Behera, N. Carbon sequestration and role of earthworms in Indian land uses: A review. Ecoscan $2013,7,1-7$.

38. Rajput, B.S.; Bhardwaj, D.R.; Pala, N.A. Factors influencing biomass and carbon storage potential of different land use systems along an elevational gradient in temperate northwestern Himalaya. Agrofor. Syst. 2017, 91, 479-486. [CrossRef]

39. Haile, S.G.; Nair, P.K.R.; Nair, V.D. Carbon Storage of Different Soil-Size Fractions in Florida Silvopastoral Systems. J. Environ. Qual. 2008, 37, 1789-1797. [CrossRef] [PubMed]

40. Jana, B.K.; Biswas, S.; Majumder, M.; Roy, P.K.; Mazumdar, A. Carbon sequestration rate and above-ground biomass carbon potential of four young species. J. Ecol. Nat. Environ. 2009, 1, 15-24.

41. Okuda, H.; Noda, K.; Sawamoto, T.; Tsuruta, H.; Hirabayashi, T.; Yonemoto, J.Y.; Yagi, K. Emission of $\mathrm{N}_{2} \mathrm{O}$ and $\mathrm{CO}_{2}$ and Uptake of $\mathrm{CH} 4$ in Soil from a Satsuma Mandarin Orchard under Mulching Cultivation in Central Japan. J. Jpn. Soc. Hortic. Sci. 2007, 76, 279-287. [CrossRef]

42. Kell, D.B. Large-scale sequestration of atmospheric carbon via plant roots in natural and agricultural ecosystems: Why and how. Philos. Trans. R. Soc. B Biol. Sci. 2012, 367, 1589-1597. [CrossRef] [PubMed]

43. Chiti, T.; Díaz-Pinés, E.; Rubio, A. Soil organic carbon stocks of conifers, broadleaf and evergreen broadleaf forests of Spain. Biol. Fertil. Soils 2012, 48, 817-826. [CrossRef]

44. Chauhan, S.K.; Sharma, R.; Singh, B.; Sharma, S.C. Biomass production, carbon sequestration and economics of on-farm poplar plantations in Punjab, India. J. Appl. Nat. Sci. 2015, 7, 452-458. [CrossRef]

45. Verma, A.; Kaushal, R.; Alam, N.M.; Mehta, H.; Chaturvedi, O.P.; Mandal, D.; Tomar, J.M.S.; Rathore, A.C.; Singh, C. Predictive models for biomass and carbon stocks estimation in Grewia optiva on degraded lands in western Himalaya. Agrofor. Syst. 2014, 88, 895-905. [CrossRef]

46. Krankina, O.N.; Harmon, M.E. The impact of intensive forest management on carbon stores in forest ecosystems. World Resour. Rev. 1994, 6, 161-177.

47. Bajigo, A.; Tadesse, M.; Moges, Y.; Anjulo, A. Estimation of carbon stored in agroforestry practices in Gununo Water-shed, Wolayitta Zone, Ethiopia. J. Ecosyst. Ecography 2015, 5, 1.

48. Winjum, J.K.; Dixon, R.K.; Schroeder, P.E. Estimating the global potential of forest and agroforest management practices to sequester carbon. Water Air Soil Pollut. 1992, 64, 213-227. [CrossRef] 